\title{
Participatory Patterns in Urban Planning and Evaluation of the Constituent Factors in the Realization of Citizen Participation with Emphasis on Communication activation
}

\author{
Sahar Golchini* \\ Master of Geography and Urban Planning \\ ailin88s@yahoo.com
}

\begin{abstract}
In the new planning patterns, the issue of citizen participation in many countries is very much considered and public participation at various levels of planning and decision making has been made. In fact, one of the most important concer ns of ur ban planners is to provide maximum satisfaction to citizens. The satisfaction of residents of a city, as a fundamental goal of urban planning, is of particular importance. But when it comes to efforts, a concept that is in tune with the economic, social and cultural structures of developed countries. In developing countries, regardless of the complexity of planning these societies, along with a host of issues and problems such as poverty, rapid urbanization and inefficiencies in providing services, infrastructure, institutional weaknesses and etc. results was not si gnificant. Obviously, new experiences show that more attention has been paid to citizen participation in planning, especially in urban development $p$ rograms. The purpose of this paper is to examine participatory patterns and views on citiz en participation in ur ban planning and form al and informal planning structures, including government and stakeholders, planning institutions, laws, regulations, tools, and conceptual model. This res earch is based on the des criptive objective and the method and tool for collecting data, do cumentary and librar $y$, which are reviewed using experts' point of view . Results According to the communicative action theory, an environment characterized by weakness of trust is an obstacle to the realization of participation in the for mal and institutional dimension. Based on the principle of communicative action, the appropriate context for the realization of citizen participation can be created by increasing trust and building civil society in the city.
\end{abstract}

Key words: urban planning, citizenship participation patterns, communication activities, planning environment.

\section{Introduction}

Participation, the key to the development and management of well-known urban plans and their realization in practice, requires a general agreement on decision-making and enforcement actions. Some common definitions refer to partnership as planning, decision making, implementation of programs and projects, investment and construction at a local level. Increasing public awareness of its interests and expanding public participation in community management has led to urban planning as an effective response to the benefits and needs and the use of their resources. Participation takes place at a variety of levels, from a level where citizens may not have any right to address urban issues until they are fully effective at all stages. The full success of a city proj ect is sometimes proportional to the lev el of stakeholder participation of project. The presence of people in the development process following the efforts of UNESCO at the 19th General Assembly in 1926 in Nairobi, it proposed a "hum an-centered development" approach and cal led for its implementation in development planning. In this approach, the need for partnership has been emphasized more than ever and has become the pivotal center of development in the world. In this development, participation was seen as an important point and it $w$ as considered as one of the fundamental aspect of the development of the internal one, according to which people consciously protect their identities and develop their individual and collective thought. Hence, the participation of the people in this process is a fundamental and practical condition that forms part of the operational aspects of development. At present, urban planning is one of the important issues of $t$ he contemporary world, which is a phenomenon of urbanization. Urban issues and the proper direction of urban development and expansion require urban planning, and it has come to the fore in order to reduce the various issues of cities and the city of urban development (Alavi Tabar, 2000). Urban planners as urban experts, in the current stage, should have practical ways of e ngaging the people, as well as fi nding ways to strengthen sustained participation in different parts of the city and the establishment of partner organizations to institutionalize the part nership in an optimal, think of them and continue to offer practical suggestions. In 
developed countries, it has been somewhat tied to the management and planning system of the people. Because of the democratic system and the institutional and le gal backing for citizen involvement in planning and governance, expanding partnerships is a legitimate goal. Since the various revenues to be paid for planning and management, it is taxed by the people, as a result of which some kind of people are created and people have the right to participate and question the authorities (Helper, 2001). In our country, participation in planning and governing is often not commonplace and $\mathrm{m}$ ay be confr onted by gove rnment and citizens (Conley, 2009). Recently, however, ne w issues ha ve been raised: legality, meritocracy, pluralism, people-centeredness, privatization, centrality of justice and the election of Islamic councils of cities. Officials seem to be gradually moving forward to engage in practical action, but a long way to come to an end. What is currently being done in projects with the title "Participation in Iran" is mainly the financing of the financial plan for the pre-sale of units. In this context, it is necessary to carefully determine the partnership planning, dimensions and levels, in partnership planning, and determine the actual status of urban projects that are re ferred to as collaborative themes (Habibi and Rezvani, 2007). According to the above, the study in this regard, both theoretically and in terms of determining the role of NGOs, is im portant in increasing public participation in society. The main objectives of this paper are to examine the fields of the formation of dialogue and participation among the main elements of the city and soci ety, and deliberate transformations in the society, which are directly responsible for human beings, in order to make quality changes in communities, human beings through interact and communicate with each other. In fact, relations based on communicative action can provide the areas in which citizens can agree on and establish a variety of social, economic, political, and cultural relations in a free and non-violent manner with each other and with the government and civil society (Hedayati and et al 2009). It is also necessary to provide the necessary grounds for establishing participation in Iranian societies and facilitating the production and distribution of resources according to the nee ds and devel oping and strengthening local organizations as a principle in urban planning, taking advantage of the experiences of successful countries in this field.

\section{Methodology}

This research has been formulated in terms of the purpose of achieving concepts in a fundamental way based on descriptive analysis. In terms of methodology based on the conceptual domain, it examines the patterns of participation and the factors affecting citizenship participation in general and the library-document method is used to collect information.

\section{Literature review}

Research has been done on citizenship participation and its patterns. In the research on "Citizen Indicators in Urban Planning "concluded that the patterns of participation were provided only to select groups of people and more than to the benefit of the collective works for group and class interests (Mahmoud Zadeh and Vareshi 2015). In the study, "An innovative model for assessing the level of participation of projects is the example of the good neighborhood". By reviewing the theory of the special scheme for the renovation of the neighborhood, has the highest level of part icipation in this plan, in the planning stages, performance and vi sion are seen (Ansari and Andalib 2016). Another study by entitled "Participatory Planning Environment; providing a conceptual model for a nalyzing the factors affecting $\mathrm{c}$ itizen participation in planning" concluded that the possibility of participation in developing countries required correct ex isting procedures and structures that require a long-term solution to the internal and external environment of planning Danzpour et al. (2016). In a research on "Investigating the Factors Affecting Public Participation in Urban Development in the City of Ilam" concluded that the social belonging and the level of participation of people, the level of popular satisfaction of their life and the willingness to participate with the variables of gender and education has a positive and significant impact on urban development in Ilam. Saffaiipour (2016). In the article "The Role of Citizen Participation in the Sustainable Development of Urban Neighborhoods in the City of Noshahr" concluded that one of the most important ways of promoting the urban development level in cities was to increase the level of citizen participation using potential and capacities. That they are in novative in u rban management. In the research "The rel ationship between citizen participation and the main factors of urban management in Tehran" citizens are mentally interested in participating in urban management, but objectively, citizen participation follows a minimum level Fakhraei and Moradi (2016). Moreover, in the external sources, research has been done as fo llows. Mr. Sap phaews (2018), in a pap er entitled "Social Capital, Citizen Participation in Governmental Management and the Functioning of the Public Sector in Thailand", while investigating the relationship between social capital and citizen participation and the performance of the public sector in Thailand, concluded that social networks were the main component social capital, it increases the incentive for participation and performance in the public affairs of citizens. In another study entitled "Citizenship Designing Science, a Strategy for the Design of Urban Creative", by Javanan and et al (2018), on the application of modern information technology and ICT for the purpose of intelligent citizenship design, while using the set of kits Qua-kit urban rapid geometry analyzes the application of geometry in the design of the environment and the appropriate tool to provide a platform for the idea of citizens in their neighborhood or 
city. In The study of Future of Citizen Participation in Cities, the Citizen Participation Council in Urb an Sustainability Strategies, called for the implementation of long-term sustainability policies for citizen participation and technical support for networks and social and m edia channels Emphasized Eliman and Feldman (2018). In a study en titled "Citizen Participation as a So cial Change Tool in Urban Spatial Rehabilitation Projects in Spain", believed that citizens' social participation in urban public projects increased spatial knowledge and public awareness from the environment of an are a Duran et al. (2018). In another study with the theme of "Clear Policies of Participatory Culture, Paradigm Models and models. Technological, social and political trends have a key role to play in the participation of Western societies, and have a significant impact on cultural behaviors and strategies of cultural institutions. Bonnet and Negre (2018). An appropriate model can illustrate the distinctive roles of current citizens in this regard, and allows critically to examine the political goals and the status of the stakeholders and the people's attitudes about the freedom of their participation. In another study en titled "Reviewing the strategies of dialogue on social media activities to strengthen citizen interactions with local governments in Latin America", have had a positive impact on the use of strategies and on the citizen's online engagement aimed at strengthening participation through social media in MERCOSUR province Garcia et al. (2018). As a result, research can provide researchers with information that avoids rework and repeated research, and helps provide new ideas and solutions

\section{Definitions and concepts}

\section{Partnership and Citizenship}

Participation: "According to the United Nations definition, is to interfere and engage people in eco nomic, political, social and cultural processes that affect their fate; in fact, participation is realized when indifference and irresponsibility place itself in a sense of dependency, fate and responsibility "(Aini et al., 2008). Engaging, helping and being responsible are the three main pillars of particip ation (Alavi Tabar, 2002). The term participation, literally means bilateral and mutual companies for doing business (Azkia and Ghaffari, 2004). Traditionally, participation is voluntarily or compulsory in local, state, and $\mathrm{n}$ ational affairs in gov ernment decisions (Milakovich, 2010). In the area of urban affairs, citizens' participation is also the foundation stone of democracy and a clear term for the power of citizens (Monash, 2008). As the participation of individuals reduces dissent, tensions and administrative barriers, decisions are made and consequently, make decisions public (Alizadeh Aghdam, 2014)

\section{Types of Partnership}

General participation: where the majority of people are involved. The characteristic of this kind of partnership is its cross-sectional nature or the creation of a common sense, such as war and revolution.

Social participation: is expressed in different classes of the society and this type of partnership is more evident based on the sources of the business and in some cases it can be transformed into public participation.

Popular Participation: This is a way of contributing to the characteristics of new societies, but we have seen this in Iran as a way of helping people in many rural areas.

This type of partnership is a fundamental right in which people wisely, with knowledge, determination and willingness in a particular and group-specific way, try to satisfy individual and group psychological needs for helping to achieve pre-determined goals based on the real needs of the priority taking into account the possibilities and limitations for finding individual and collective identity in so ciety. Now, if we consider the scope of participation as a city and consi der a process of planning with a participatory framework and involve factors such as social justice, sustainable development, we will have participatory urban planning (technical and sincere, 2009), Fig. 1.

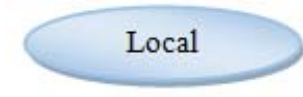

Local participation

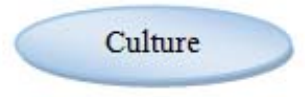

social participation
Power

\section{Political participation}

Figure 1: Types of Participation by Activity (Nick P, 2011) 
Citizenship: "Citizenship in the contemporary world has disappeared from its tru e meaning. Citizenship is considered to be the most dynamic social concept of modern society. In other words, the foundation of civil society is based on the social institutions of the citizenship system. Citizenship is a kind of social activity and a series of government rights to people and people over the state, as well as a common sense of national and social identity in a certain area. The essen tial feature of citizenship is the existence of participation ethics (Ghaffari Nasab, 2010). Therefore, according to citizenship theories, the common core of the definition of citizenship is as follows:

A kind of base and a modern social role for all members of society

An interconnected set of duties, rights, duties, responsibilities and social, political, legal, economic and cultural equal rights

Feeling of modern social membership for active and active participation in society and economic, political, social and cultural spheres

Fairly and equitably all members of the community from the benefits, resources and privileges of s ocial, economic, political, legal, cultural and security, regardless of class, racial, religious or ethnic belonging (Jiabari and Safari, 2010)."

Citizen: "A person who is present in the social, political, cultural and social structure of the society, and in decision making, shaping it directly or indirectly in the shadow of coexistence, voluntary engagement and cooperation in achieving worldly prosperity, and E ffective in the future ". In fact, one of the rights of citizen participation, the development of the city's municipality in exploiting all aspects of the city's space with $t$ he structural roots of ci vil society that accompany growth and excellence. Citizens' rights a re encouraged to participate in the development of sustainable economic, social, and environmental protection (Damavia et al. 2009).

\section{Citizenship Participation Levels}

Participation of citizens is realized at different levels and degrees, in other words, between ceremonial and fictitious participation; and participation that shows actual power of influence in the results and process of planning is very different (Ziari et al., 2009). Today, in urban development issues, humanitarian issues are prioritized, and concepts such as participation as the main pillar of urban development are discussed. In general, the space that followed the thinking of modernity has provided a platform for the concept of participation. In general, people's participation in the plan is:

A: Participation in planning and decision making

B: Participation in the implementation of the projects

C: Partnership in operation

C: Participation in evaluation (Schap, 2009)

\section{Factors Affecting Urban Participation and Its Preconditions}

The concept of modernity is associated with the problem of urban transformation and the growth of urbanization and the emergence of new social institutions, the presence of people in various fields and the creation of legal systems (Jaberi Moghaddam, 2005). In fact, the most important feature of this approach is the acceptance of man as the s ole source of determining values. One of the most important products of modernity is also the importance of democracy as an effective military system for managing political affairs in society. Democracy, with an em phasis on e quality between men, in fundamental rights a nd in access to opportunities for the realization of talents, provides favorable conditions for the widest possible participation of individuals in the process by increasing the chances of survival and growth of the ecosystem (Paya, 2008).

Also, concepts such as citize nship were also introduced in these terms. Urban participation is affected by a variety of factors that need to be considered in the adoption of urban participatory approach and urban planning. Among these factors are the intentions of the participants, their motivation to participate in the city, the participants' expectations of the results and the rewa rds of participation and finally the opportunities and conditions for participation of the city. The set of these factors affects the formation of urban participation and the nature of urban participation (Kazlai, 2000). In this context, the main preconditions for the realization of urban participation are:

- The existence of urban participatory culture (cultural education and promotion);

- The formation of ap propriate economic, social, political, cultural and urban structures suitable for urban participation at the local (urban and rural), regional (provincial) and national levels (macro level);

- The existence of urban management system (municipalities and city councils) "participatory, participatory and participatory" 


\section{Views on popular participation in urban planning}

The most fundamental idea of the infrastructure of participation is to accept the principle of equality in opportunities for the people. Adoption of the principle of equality is an opportunity for the people. Participatory views originate from various theories about the structure and functioning of local governments in particular, and from various theories on labor participation in general.

The development of civil society depends on the process of internalization and institutionalization of public participation and the strategies for increasing citizenship participation in the three processes of internalizing the values of participation, the institutionalization and reduction of social disorders, the development of civil society through the formation of unions and syndicates and Guilds (Scientist and Nazariyan, 2010). According to Daniel H Stroub, philosophical views on popular participation can be divided into four categories :

\section{Build the theory}

In this view, because local residents and people are not, in principle, able to play a constructive role in the implementation of projects, their participation can only be used to reduce their opposition to projects through formal interference. In other words, making people appear to be involved in participation in order to avoid creating intermediate obstacles for future urban plans and programs (Moradi, 1997).

\section{\#dvisory Opinion}

According to this view, contrary to the theory of bringing together, the values raised by planners and policymakers in the public interest are basically the values that belong to the middle class (Western perspective) and cannot meet the needs of the lower economies. Therefore, communication between people and citizens in order to understand their thoughts and their values is one of the requirements of planning. This theory emphasizes three trends, including informing residents about existing options, taking citizen's opinions, incorporating community thoughts into plans or final plans.

\section{Educational-social therapy theory or social learning model}

The promotion of the status of citizens through education, which is given through participation and the training of responsible citizens, which can bring their own destinies to the optimal level with the freedom and democracy they provide. The basis of this theory is, in fact, democracy. People who believe in this theory believe that popular participation provides a good educational ground for the education of citizens and is based on it. It can only be affected by the participation of local residents in the programs and citizens can by training, they will gain the power to improve their situation. This model is also called the "Social Learning" model, which was originally John Friedman who believed that one should remove the planners as lawyers from the public and people as distance clients, and the scientific language of planners to the people and the language of practical facts of the people is taught to planners (Andrew and Herchil, 1997).

\section{Community Power Theory}

Accordingly, these individuals and societies that have be en far removed from the center of social power for various reasons, should be involved in policy-making. This theory is generally radicalized and differs from other theories. According to this theory, there are mainly two approaches to the function and role of local governments. The first approach: the local approach, aimed at increas ing the control of citizens, is trying to establish their political power base. The second approach is to empower local governments by locating local people in independent policy-makers in low-income regions through the establishment of ne ighboring organizations (Hanachi, 2000).

\section{Expansion of People's Participation in Urban Planning System in Iran}

Applying people's participation in urban planning is likely to allow the system to use public opinion and be organized in such a way as to enable people's involvement in the planning process. In terms of planning, during the three decades of 1960-1990, urban planning came to a participatory model from a very elitist perspective. In a theoretical context and in an effort to escape from passivity, there were different perspectives, but the tendency to attract po pular participation in planning, along with criticisms of the liberal and non-political economiceconomic system, led the planners' attention to the application of the theory of action getting connected (Haley, 2009). The most important change required in the way of reviewing and approving programs is the change in the role of the people, which can strengthen the presence of representatives of collective councils to direct referrals to public votes in the review and approval of programs. In Iran there is little experience of participatory planning in urban affairs. Using the pattern of community planning and relying on professional urban planning institutions in the country has limited the level of participation of people in planning to get information about the city's situation and some limited information. In the current Urban Planning Process in Iran, Urban Planning Professional institutions conduct all stag es of planning and designing projects. The status of $\mathrm{participation}$ in urban planning laws in Iran is carried out within the framework of several laws and regulations. These laws and regulations are drafted and approved by the Islamic Consultative Assembly, the Government, the Supreme Council for Urban Development and Architecture and the Ministries of Roads and Urban Development. The 
regulations regarding the determination of the status of peo ple and councils in the urban planning process include the two groups of regulations concerning the determination of the scope of duties and authority of the councils and the provisions for determining the extent of urban planning, including the process of preparation and approval. In t hese two groups of laws, reference is made to the role of people and councils and the requirements for interaction between the body of planning and approval of urban plans and popular institutions such as co uncils. The i ndividuals and groups involved in urban planning involve the state and planning institutions and the people that are the most important factors in urban planning. Each of these factors plays a role in planning. In Iran, the role of government and professional planning institutions has been largely determined by the rules and regulations. Along with these factors, people have a different fate as planning audiences and those who plan for them. The participation of this part of urban planning factors in the laws and regulations has been mentioned and has mainly caused the attention of scientific and governmental circles in recent decades to the participatory planning approach. In the present situation in Iran, effective participation of the people and their representatives in the process of urban planning is lim ited to its adoption. Their participation in the city's id entification process also has no effect on the solutions and suggestions of the program, and is only done for the dignity. This situation is due to the lack of binding rules and regulations for participation of people and councils in the planning process.

Achieving this goal and benefiting from its results requires changing the approach to urban planning to facilitate people's participation in this process and legitimate support for this approach. In fact, the participation of these people along with the people in the urban planning process can increase the extent to which urban projects are realized by the public. Therefore, it will be necessary that the new system of planning the country, leaving the framework, narrow central planning from the top to bottom, regardless of the demands of the local people, the popular concept and the planning of cities alo ng with the crystallization of the views of the people and the interpreter of the macroeconomists government in perfect harmony. Figure 2.

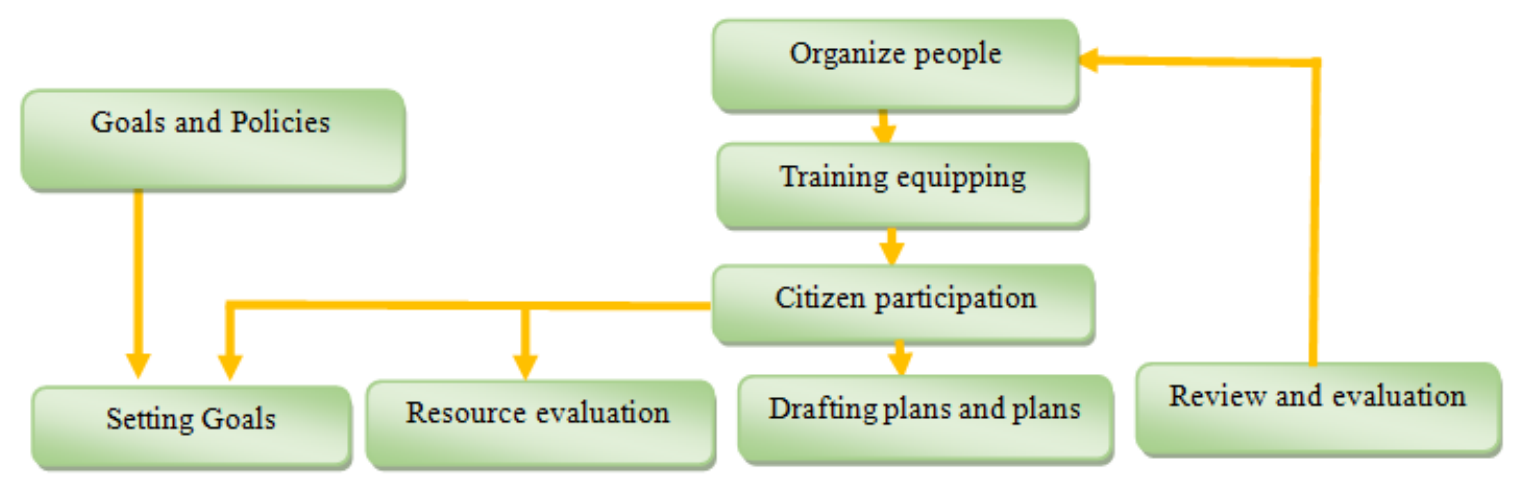

Figure 2: How to Participate in Citizenship and Its Position in Urban Planning in The Need for Implementation of Communication Planning Approach in Developing Countries

Given the fact that communication planning has been introduced in developed countries, it is necessary to provide the potential of this type of planning for use in developing countries and the being discussed. In fact, urban planning in developing countries, with a simple-comprehensive or rational-comprehensive approach and focus on physical aspects, has not had much significant results and has failed in the implementation and provision of resources, and the need to pursue participatory practices in these countries is known (Rocky, 2001). Networking, as well as redistribution of power among the stakeholders, is one of the strengths that can make communication planning a good result in Iran. In more advanced countries, formal and informal groups such as environmental groups or economic entities are involved in formulating a program from start to finish in different ways. The weakness of popular participation or such groups in Iran and their lack of presence in the urban planning process can show the will of the community has led to a lack of planning so far (Alavi Tabar, 2003), Figure 3. 


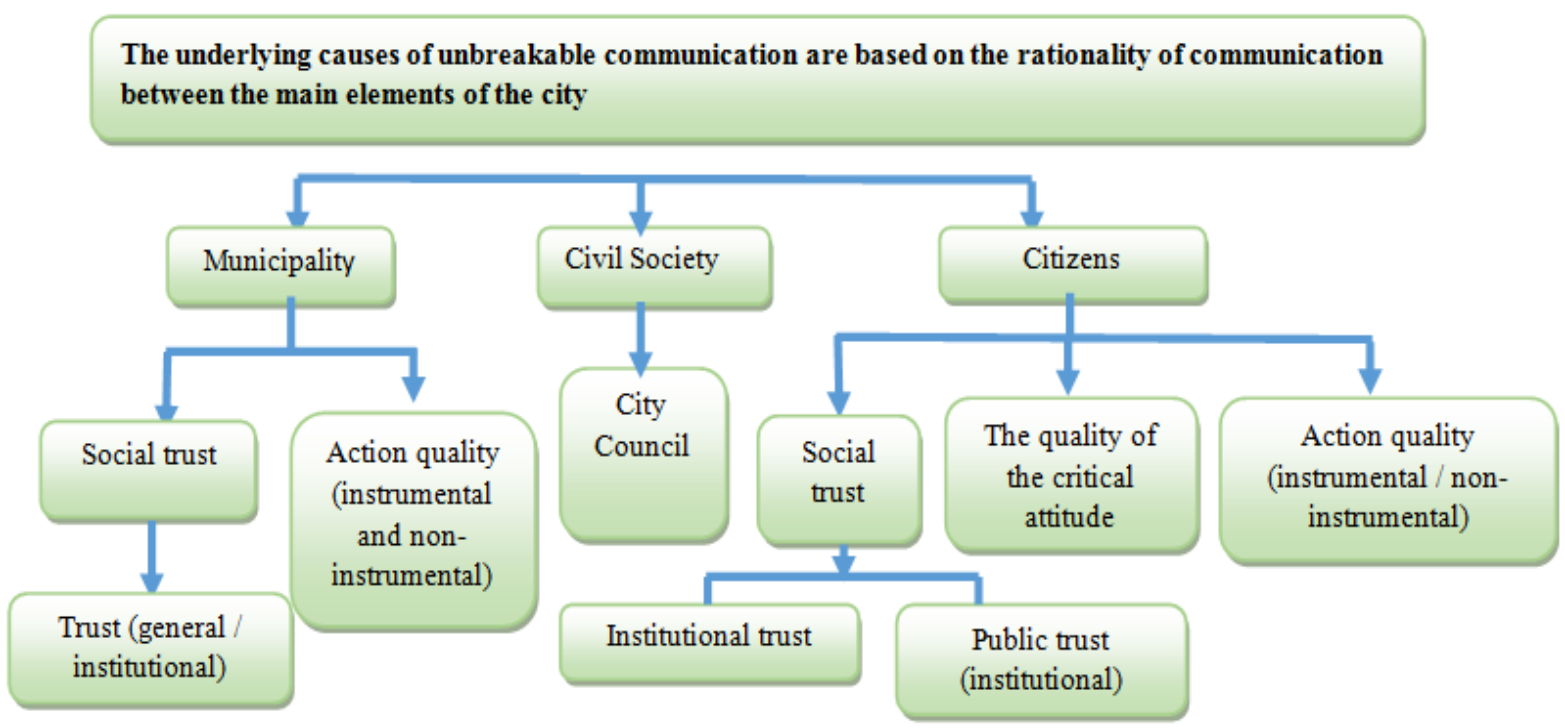

Figure 3: Understanding the Participation and Factors of Distorted Communication Based on the Habermas Principles in Iran

Studies show that the lack of trust and weakness in civil society causes the lack of formation and participation in action. But why, with the establishment of the highest levels of civil society in the cities and villages of the country in the form of rural and urban councils, does not mean the participation of the factual and formal face? In fact, the lack of a corr ect solution, in the interactions and communication of the main elements of the city together, according to the principles of communication theory, causes the distance between these elements, and this distance has led to a lack of trust between them, so that $\mathrm{c}$ ommunicative action and form appropriate communication can bring about the proximity and trust between the main elements of the city. In this section, it is necessary to refer to the concepts of modernity, modernism, and modernization.

Modernity is a rational approach that reflects this continuous movement forward. Innovative modernity occurs in the mind and the outside world, and its realization is based on the founding of modern foundations in human thought. This concept is associated with the problem of urban transformation and the growth of urbanization, the emergence of new social institutions, the presence of people in various fields and the creation of legal systems in their historical direction. But modernism is a kind of ideology that seeks to replace the old rather than the old, and considers the new to be superior to the old, and a process planned and guided by the determination of the individual or its people and m odernization is the most efficient layer of th is process. That is, practical modernization is the result of modernism based on modernity and modern thoughts (Jaberi Moghaddam, 2005). This cultural breakthrough makes it impossible for the outward appearance of modernity in the structure of Iranian urban management, like city councils, to convey its meaning, because the appropriate context for this transition has not been provided. In general, it can be said that in order to realize participation, the cultural and social contexts that are needed in the developed countries of these areas are due to the transformations of modernity. But in a country such as Iran, due to cultural cessation and modernity, the old values of Persian origin and social norms, especially social distrust, are lost (Rostamzadeh et al., 2010) and concepts derived from modernist thinking such as participation, the realization of partnership is facing dichotomy. Due to this dichotomy, despite all the tricks of experts and even the structure of urban management, the realization of social trust as an important obstacle to the achievement of urban development is posed

\section{Investigating the underlying factors in relation to the realization of citizenship participation}

One of the most important and fundamental factors in the failure of citizen participation from the power point of view is their resistance to the redistribution of power. (Arnstein, 1969, Yetano, royo and Acerete, 2010). It has always been an undeniable tension between the people's right to participate. There is more and public authority as a decision-maker (King, Felty and Susel, 1998). Hence communication planning researchers often believe that forms of participatory planning based on public consultation can lead to a decision process It is fairer to overcome the power differences between citizens and stakeholders (Hopkins, 2010). In ter ms of citizens, the ineffectiveness of local communities from the political, socioeconomic and infrastructural aspects, knowledge and awareness, and the difficulty in organizing representative and accountable groups, despite uncertainty and distrust, is an important barrier to citizen participation. The public participation in planning processes can be unpredictable and unreliable, and inequalities of power and income often threaten collaborative processes. (Arnstein, 1969) Forrest (2006). Various stakeholders may interfere with participation processes, act stereotyped and exploit issues of their own. In his view, effective public participation in public planning and management requires technique and initiative. To accomplish this, it is necessary to consider strategies such as diplomacy and division of roles. Also, skillful mediation activities can change the real contradictions in the relationships and 
practical arrangements by making use of sustained and innovative efforts. Studies show that those who benefit most from participation are a major obstacle to the development of participatory initiatives. Therefore, it can be argued that the mechanisms of civil participation act in a range of countries with different political, economic and social systems. But how they are realized and how successful they are in practice is not the same, and many countries, including Iran, are at the beginning of this difficult path. Despite the fact that so far many studies have been conducted to identify benchmarks for evaluating participatory programs and to a more limited extent in order to identify the barriers and requirements for the realization of public participation, most of which have presented general and temporary frameworks and analyzed public participation. All the components affecting public participation are extracted and described in the diagram and Table 2

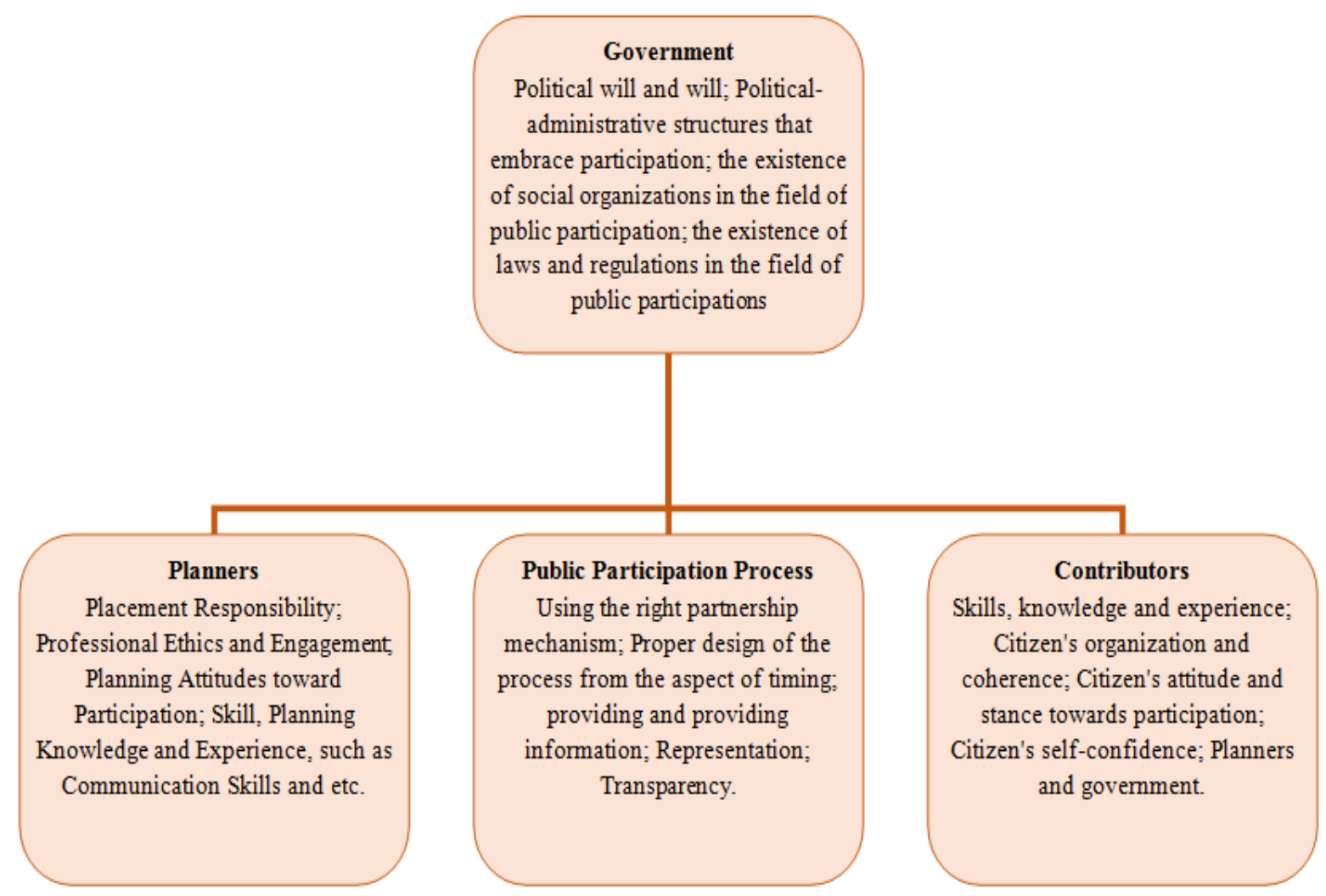

Figure 4: The underlying components and potential impacts associated with the realization of public participation 
Table 2: Components related to each of the variables that affect the realization of public participation

\begin{tabular}{|c|c|}
\hline \multicolumn{2}{|r|}{ Effective background variables in popular participation } \\
\hline Government & $\begin{array}{l}\text {-The structure of the a dministrative political system embraces partnership and resilience to } \\
\text { change; Yang \& Pandey, 2011; Ebdon \& Franklin, 2006; Yetano, } 2010 \\
\text {-Deconcentration and power distribution at different levels; Yang \& Pandey, 2011; Webler, } \\
\text { Tuler \& Kru eger, 2001 - Petition and political will; Bonafede \& Lo Piccolo, 2010; Yang \& } \\
\text { Pandey, } 2011 \text { - The existence of social organizations in the field of public participation, such } \\
\text { as community councils, specific groups of trade; al, } 2010 \text { Yetano, et-The existence of legal } \\
\text { and regulatory mechanisms for reviewing decisions; Alexander, } 2008 \text { - The existence of laws } \\
\text { and regulations In the public domain; Yang \& Pandey, 2011; Abelsona, et al., } 2007 \text { - Political } \\
\text { Stability and Policy Stability; Brownill \& Parker, } 2010 \\
\text {-Management, knowledge and experience of official officials and accountability of officials; } \\
\text { Brownill \& Parker, 2010- Connelly, 2010 } \\
\text {-The trust between the local government and the local community and the existence of } \\
\text { incentive and punitive policies; Yetano, et al., } 2010 \text { Abelsona et al., } 2007\end{array}$ \\
\hline Planners & $\begin{array}{l}\text {-Skills of knowledge and experience of planners, such as communication skills; Conrad, et } \\
\text { al., 2011; Yang \& Pandey, } 2011 \\
\text { Professionalism and Commitment; } 2011 \text { Abelsona et al., 2007; Conrad, et al } \\
\text {-Planning Plans for Participation, Adoption of Participation Results by Planners; Brownill \& } \\
\text { Parker, 2010; -Abelsona, 2007 } \\
\text {-Participation experiences; Yetano et al, } 2010 \\
\text { Attempt, Audacity and Creativity; } 2010 \text { Abelsona, et al., 2007; Brownill \& Parker } \\
\text { Plagiarism Response; Abelsona, et al., } 2007\end{array}$ \\
\hline Contributors & $\begin{array}{l}\text {-Science, knowledge and experience of citizens through formal education; Beierle, } 1999 \text {; } \\
\text { Abelsona, et al., } 2 \text { 007- \& Pan dey, } 2011 \text { Yang-The attitude and stance of citizens towards } \\
\text { participation, motivation and willingness to participate; Yetano, et al ., 2010; Brownill \& } \\
\text { Parker, 2010; Conrad et al., } 2011 \\
\text { Citizens' Organizations and Coherence; } 1999 \text { Gaventa \& Valderrama - Citizen Interaction } \\
\text { with Planners and Officials (Communication Skills); Conrad, et al., } 2011 \\
\text {-Citizen's trust in planners, citizen's trust in government (political trust), self-confidence of } \\
\text { citizens; Ebdon \& Franklin, } 2006 \\
\text {-Solidarity and social capital; albelsona, at. Al, 2007, ran } 2011 .\end{array}$ \\
\hline $\begin{array}{l}\text { Participation } \\
\text { process }\end{array}$ & $\begin{array}{l}\text {-Correct use of pa rticipatory mechanisms, such as reliance on a limited number of } \\
\text { techniques, the ap propriateness of p artnerships with goals, and the u se of m ultiple } \\
\text { mechanisms; Yang \& Pandey, 2011; Ebdon \& Fr anklin, 2006; Conrad et al., 2011; } \\
\text { Alexander, 2008 } \\
\text {-the correct design of the process in terms of timing, time of citizen intervention and process } \\
\text { continuity; Rowe \& Frewer, 2004; Ran, 2012-Marsh \& Frewer, 2004; Conrad et al., } 2011 \\
\text {-Table and provide information such as ea sy access to inform ation, lack of selective and } \\
\text { inadequate information; Conrad et al., 2011; Yang \& Pan dey, 2011; Abelson et al, } 2007 \text {; } \\
\text { Alexander, } 2008 \\
\text {-Providing information in a convenient and understandable way for citizens and informing } \\
\text { and promoting the process; Yang \& Pandey, 2011; Abelson et al., 2007; Conrad et al., } 2011 \\
\text {-Displacement (population and geographic coverage); Marsh \& Frewer, 2004; Conrad et al., } \\
\text { 2011; Yang \& Pandey, 2011; Transparency, Equal Opportunity; 2012 Webler, Tuler \& } \\
\text { Krueger, 2001; Yang \& Pandey, 2011, Conrad et al., 2011; Ran - a process based on the } \\
\text { needs of each government; Webler, Tuler \& amp; Krueger, 2001. }\end{array}$ \\
\hline
\end{tabular}




\section{Conclusion}

The most important areas of urban planning are social and cultural dimensions. Because urban planning relates directly to the values, behavioral actions, and attitudes of citizens and planners. Studies have shown that the process of urban planning theories tends to focus more attention on the social and cultural characteristics of all users, avoiding the provision of oppressive solutions, and moving towards the use of as many ideas as possible. People have been in the process of urban planning and design. Communication planning is one of the new ways to meet these requirements. The communication process requires knowledge and information from the target environment. One of the main reasons for the poor performance of urban programs, despite the large capacity of large-scale laws in this area, is the personal demands and social structure of the community, which has faced public participation with difficulty. In other words, the underlying cause of low spatial planning efficiency can be found in the fundamental issues of the city an $d$ society. This has led to complicated and ina ppropriate conditions for rational planning. Obviously, moving in this direction requires the provision of necessary fields. In order to achieve an increasing interactive and interactive environment within the community, before any factor, it is necessary to consider the establishment of or ganizational and managerial foundations of society, which reaches the level of interaction, requires the definition of ad ministrative and institutional and institutionalization, which is through the integration of theories about the environment programming ground and participatory planning theories can help identify the features of a planning environment that can limit participation planning in different contexts. In this study, we have identified a large perspective on planning, models and theories related to the planning environment, with an emphasis on planning culture and effective components of participatory planning, especially the realization of public participation in the planning environment. At the same time, formal and informal structures have been explored in this environment, which includes the external areas of participatory planning (government-partners, etc.) and the intern al planning of participation (planners and planning institutions - Laws and regulations, etc.) and can help in Iran and in the area of citizen participation 
Table 3: Analysis of effective factors on the realization of citizen participation according to the variables of the participatory planning environment

\begin{tabular}{|c|c|c|c|}
\hline $\begin{array}{l}\text { Planning } \\
\text { Environment }\end{array}$ & $\begin{array}{l}\text { Analysis } \\
\text { environment }\end{array}$ & Formal structures & एس山سயUnofficial structures \\
\hline $\begin{array}{l}\text { The external } \\
\text { environment } \\
\text { of } \\
\text { participatory } \\
\text { planning }\end{array}$ & Government & $\begin{array}{l}\text { - The structure of the political } \\
\text { and administrative system } \\
\text { accepting participation } \\
\text { - Distribution of power at } \\
\text { different levels } \\
\text {-Political sustainability and } \\
\text { policy stability } \\
\text { - The country's economic } \\
\text { structure }\end{array}$ & $\begin{array}{l}\text { - Will and political will } \\
\text { Historical relationships and trust between } \\
\text { the government and local communities\# }\end{array}$ \\
\hline & $\begin{array}{l}\text { Contributors } \\
\text { (community) }\end{array}$ & $\begin{array}{l}\text { - Knowledge and experience of } \\
\text { citizens } \\
\text { - Creating social n etworks in } \\
\text { order to gain knowledge and } \\
\text { power } \\
\text { - Organization of citizens in the } \\
\text { form of non-governmental } \\
\text { organizations, associations and } \\
\text { so on } \\
\text { - Activities of citizens with } \\
\text { planners and official officials }\end{array}$ & $\begin{array}{l}\text { - The general features of s ociety, such as } \\
\text { individualism, passivity, and so on } \\
\text { - Volitory values to society } \\
\text { - The moral responsibility and obligations } \\
\text { of society } \\
\text { - The Citizens' Perspectives on } \\
\text { Participation } \\
\text { - Trading the citizens } \\
\text { - Thanks and willingness to participate } \\
\text { - Legal affiliation and social capital }\end{array}$ \\
\hline & $\begin{array}{l}\text { Planners and } \\
\text { planning } \\
\text { institutions }\end{array}$ & $\begin{array}{l}\text { - Skill, knowledge and } \\
\text { experience } \\
\text { - Activities of planners and } \\
\text { official officials } \\
\text { - Participation experiences } \\
\text { - responsiveness } \\
\text { - Financial and human resources } \\
\text { allocation an certain social } \\
\text { - There are } \\
\text { organizations such as } \\
\text { neighborhood councils } \\
\text { - Equilibrium in th e regulatory } \\
\text { mechanisms of the responsible } \\
\text { institutions } \\
\text { - Paperwork }\end{array}$ & $\begin{array}{l}\text { - Attitudes and Acceptance of Planners } \\
\text { and Planning Institutions to Participation } \\
\text { Beginner, Audacity and Creativity } \\
\text { Professionalism and commitment } \\
\text { - Playing planners and officials to engage } \\
\text { in public participation } \\
\text { - Cognitive and professional norms and } \\
\text { frameworks } \\
\text { General Objectives and Objectives and } \\
\text { Planning Oriented Plans for Accepting the } \\
\text { Results of Participation } \\
\text { - media }\end{array}$ \\
\hline $\begin{array}{l}\text { The internal } \\
\text { environment } \\
\text { of } \\
\text { participatory } \\
\text { planning }\end{array}$ & $\begin{array}{l}\text { Terms and } \\
\text { Conditions }\end{array}$ & $\begin{array}{l}\text { - The existence of rules and } \\
\text { regulations in the field of public } \\
\text { participation (influencing } \\
\text { decisions, requirements for } \\
\text { participation at different levels } \\
\text { of planning, the requirement for } \\
\text { the use of participatory } \\
\text { techniques, etc.) } \\
\text { - The existence of legal and } \\
\text { regulatory mechanisms for } \\
\text { reviewing decisions } \\
\text { - the incentive and punitive } \\
\text { policies }\end{array}$ & \\
\hline
\end{tabular}




\begin{tabular}{|l|l|l|l|}
\hline \multirow{5}{*}{$\begin{array}{l}\text { Tools and } \\
\text { procedures }\end{array}$} & $\begin{array}{l}\text { Using the proper participation } \\
\text { mechanisms } \\
\text { - The correct design of the } \\
\text { process } \\
\text { - Table and provide information } \\
\text { - Representation } \\
\text { - Functionality } \\
\text { - Bid and fair (Equal } \\
\text { Opportunities) } \\
\text { - A needs-based process }\end{array}$ \\
\hline $\begin{array}{l}\text { External } \\
\text { developments }\end{array}$ & $\begin{array}{l}\text { Such as the impact of globalization trends, developments in information and } \\
\text { communication systems, political and economic developments in the region, } \\
\text { changes in the theory and practice of planning in the global arena and its } \\
\text { component, }\end{array}$ \\
\hline
\end{tabular}

\section{Reference}

[1] Abbaspour, Ibrahim, 2011, Methodological Review of Habermas's Theory of Communicative Action with a Critical Approach, Social Knowledge, Second Year, No. 64-35.

[2] Abelsona, J., Forest, P. G., Eyles, J., Casebeer, A., Martin, E., \& Mackean, G. (2007). Examining the Role of Context i n the Implementation of a Deliberative Public Par ticipation Experiment: Results from a Canadian Comparative Study. Social Science \& Medicine, 64, pp. 2115-2128.

[3] Aini, Mohammad, Jamshid Zadeh, Mohammad Ebrahim and Mohammad Dost, Mohammad Reza, 2008, Public Participation i n the Development of Integrated Urban Reflection, Iran, Mashhad.

[4] Ammadian, Power and Optics, Mokhtar, 2010, Modernity of the Place of Democracy, Political Science Quarterly, Third Year, No. 9.

[5] Ansari, Samina and Andalib, Alireza, 2014, A New Model for Asses sing the Participati on Rate of Proje cts, A Sa mple of Good Township, Shahshahan's Journal, No. Six, 13-5.

[6] Alexander, E. (2008). Public Participation in Planning A Multidimensional Model .Planning Theory \& Practice, 9(1), pp. 57-90.

[7] Ali-Alireza, 2003, Investigating the Pattern of Citizen Participation in the Ad ministration of City Affairs, (Global Experiences), Publications of the Municipal Organization, Volume II, Tehran.

[8] Ali-Alireza, 2000, A Patte rn of Citizen's Par ticipation in the Ad ministration of City Affairs, Publications of the Organization of Municipalities, Volume I, Tehran.

[9] Allmendinger, P. T.-j., M. (2002). Planning Futures-New Directions for Planning Theory London \& New York: Routledge.

[10] Andrews Patricia \& Herschel Richard (1997) Organizational Communication: Empowerment in a Technol oogical Society, Delhi : Houghton Mifflin

[11] Arnstein S. R. (1969). a Ladder of Citizen Participation. Journal of the American Institute of Planners (JAIP), 35 (4), $216-224$.

[12] Arvarji, Mohammad, 2008, Post modern Planning and Rotation, Translated by Aref Aqvami Moghaddam, Proceedings of Urban Planning Theory, Azarakhsh Publications.

[13] Asalani, Afshin, 2000, Position and role of participatory management in the urban management of new cities (new town of Pardis) , Master dissertation, Shiraz University, Shiraz.

[14] Azkia, Mostafa and Ghaffari, Alireza, 2004; Rural Development in Iran, T Publishing, Tehran.

[15] Bashirieh, Hossein, 2008, the Histor y of Political Thoughts in the Twentieth Century, Volume I, Marxist Thoughts, Eighth Edition, Tehran, Nayer Nay.

[16] Berkpur, Naser, 2007, Urban Governance and City Administration in Iran, First Conference on Urban Management and Planning, Ferdowsi University of Mashhad, Mashhad

[17] Beierle, T. C. (1999). Using Social Goals to Evaluate Public Participation in Environmental Decisions. Policy Studies Review, 16 (34), pp. 75-103.

[18] Birkland jenis. (1991). An Ecofeminist Critic Of Mainstream Planing The Trumpeter: Journal Of Ecosophy V.8.N.2.

[19] Bonafede, G., \& Lo Piccolo, F. (2010). Participative Planning Processes in the Absence of the (Public) Space of Democracy. Planning Practice \& Research, 25(3), pp. 353-375.

[20] Brownill, S. (2009). The Dynamics of Participation: Modes of Governance and Increasing Participation in Planning. Urban Policy and Research, 27 (4), pp. 357-375,

[21] Conrad, E., Cassar, L. F., Christie, M., \& Fazey, I. (2011). Hearing but not listenin g? A par ticipatory assessment of public participation in planning. Environment and Planning C: Government and Policy, 29, pp. 761-782.

[22] Connelly, S. (2010). Participation i n a Hostile State: How do Planners Act to Shape P ublic Engagement in Politically Difficult Environments?. Planning Practice and Research, 25(3), pp. 333-351

[23] Daneshpour, Seyyed Abdul Hadi, Behzadfar, Mostafa, Berkpoor, Naser and Shar afi, Marjan, 2016, Participatory planning environment; Conceptual model for the analysis of factors affecting citizen participation in planning, Quarterly Journal of Architecture and Urban Planning, No. 18, 41- 23

[24] Deakin, Mark. (2009) “A Community-Based Approach to Sustainable Urban Regeneration.” Journal of Urban Technology 1( 16).

[25] Ebdon, C., \& Franklin, A. L. (2006). Citizen Participation in Budgeting Theory. Public Administration Review, 66(3), pp. $437-447$.

[26] Ebrahimi, Leila and Alizadeh, Amir, 2016, The Role of Citizen Participation in the Sustainable Development of Urban Neighborhoods Case Study, Nooshahr City, 12th International Conference on Civil, Architecture and Urban Planning, Contemporary Iran, Tehran, 121.

[27] Faculty, Fetaneh and Nazariy an, Asghar, 2009, Strengthening the Citizenship Morality in Managin g Metropolises, Geolo gical Quarterly, Amayesh Malayer Environment, Third Year, No. 8.

[28] Fakhraei, Abbas and Bazizi, Rozhin, 2016, Inve stigating the relationship between citizen participation and the main factors of urban management, Tehran case study, Environmental studies journal of Haft Hesar, No. 21, 26-17. 
[29] Fanni, Zohreh and Sadeghi, Yadollah, 2009, Empowerment of Marginalists in the Process of Improvement and Modernization of Urban Textile Texture, Quarterly Journal of Malayer Environment, Islamic Azad University, Malayer Branch, No. 7, 73-53.

[30] Feyian, Mojtaba and Shahin Rad, Maynoush, 2009, Municipality Development Strategy for Urban Development with Emphasis on the Strategic Plan of Kerman, Iranian Journal of Social Studies, Volume II.

[31] Forester, J. (2001). An Instructive Case st udy Hampered by Theoretical Puzzles, Criti cal Comments on Flyvbjerg`s. Rationality and Powe. International Planning Studies 6(3).

[32] Francisco, Durán. Vian, Miriam.Serrano, Martínez. Juan, José Pons, Izquierdo. (2018). Citizen participation as a social shift tool in projects of urban fluvial space recovery: A case study in Spain, Urban Forestry \& Urban GreeningVolume 31, April 2018, Pages $252-$ 260.

[33] Gafari Nasab, Esfandiar, 2012, The role of active citizenship in improving the quality of urban life, Journal of Urban S ociological Studies, No. II.

[34] Gaventa, J., \& Valderrama, C. (1999). Participation, Citizenship and Local Governance. Background Note Prepared for Workshop on 'Strengthening Participation in Local Governance', Institute of Development Studies (IDS), Brighton, June 21-24.

[35] Gulling Worth, J. B . ( 1997). Planning in USA. London: Routledge.

[36] Habibi, Seyyed Mohsen and Seyed Rezvani, Hadi, 2005, Participatory Urbanism, Theoretical Exploration in Iran, Fine Arts, No. 24, 24-15

[37] Heidari, Hamid Reza and Mah moudzadeh, Mohammad, 2016, Evaluat ion of Citizen In dicators in Urban Pl anning, Geographic Quarterly, Forty-Seventh Number, 115-100.

[38] Healey, P. (1993). Planning T hrough Debate: T he Communicative Turn in Planni ng Theory In: F. Fischer, J. Forester: The Argumentative Turn in Policy Analysis and Planning (pp. 223-253.): UCL press.

[39] Healey, Patsy, 1997. Collaborative Planning: shaping places in fragmented societies, Macmillan Press, London.

[40] Hillier,J.(2003).Shadows of Power: An Allegory of P rudence in land - use planning, London and New Y ork: Taylor \& Francis Rutledge.

[41] Hosseini, Seyyed Ali, 2001, Methods of Citizen Participation in Urban Development Plans in Rasht, Ph.D. in Geography and Urban Planning, Tarbiat Modares University, Tehran.

[42] Honahi, Simin and M oradi Christian, Araz, 2001, Participatory urbanization, Popular participation in Ur ban Planning and Development, Ministry of Housing and Urban Development, Center for Urban and Architectural Studies.

[43] Hopkins, D. (2010). The emancipatory limits of participation in planning; Equity and power in deliber ative plan-making in Perth, Western Australia. TPR, 81 (1), pp. 55-81

[44] Izari, Karmatollah, Zandi, Sayed Majeddin and Aghajani, Mohammad, 2009, Investigating citizenship participation and its role in the management of small towns, Case study of grasshopper city, Varzaneh and Hojj, Geography and Regional Development Magazine, No. 13, $235-211$.

[45] Jaberi Moghadam, Morteza, 2005, City and Modernity, Organization for the Publishing and Publishing of the Ministry of Culture and Islamic Guidance

[46] Johannes, Muellera. Hangxin, Lub. Artem, Chirkinb. Bernhard, Kleina. Gerhard, Schmittb. (2018). Citizen Design Science: A strategy for crowd-creative urban design, Cities Volume 72, Part A, February 2018, Pages 181-188.

[47] Kaghdam, Alireza, 2013, Urban Inst itutions and Citizen Participation in the Administration of Urban Affairs, Case Study: Isfahan, Quarterly Journal of Human Geography Research, No. 3.

[48] King, C. S., Feltey, K. M., \& Susel, B. O. (1998). The Question of Participation: Toward Authentic Public Participation in Public Administration. Public Administration Review, 58 (4), pp. 317-326.

[49] Lluis, Boneta. Emmanuel, Négrierb. (2018). The participative turn in cultural policy: Paradigms, models, contexts, PoeticsVolume 66, February 2018, Pages 64-73.

[50] Mahdizadeh, Javad, 2001, toward humanistic urbanization, Urban Management Quarterly, Second Year, No. 5.

[51] Maria, del. MarGálvez-Rodrígu, ezAlejandroSáez.-Martín, Manuela. García-Tabuyo, Carmen Caba-Pérez. (2018). Exploring dialogic strategies in social media for fostering citizens' interactions with Latin American local governments, Public Relations Review Volume 44, Issue 2, June 2018, Pages 265-276.

[52] Moradi, Consultant (Mazand Urban Development and Development in Mazandaran Province), Proceedings of the Fourth Conference of Urban Worn Urban Textiles, Tehran, National Organization and Housing, 1997

[53] Murry, J.W. \& Hammons ,j .o. (1995). Delphi: a versatile methodology for conducting qualitative research. The Review of H igher Education. Vol,18. No ,4.

[54] Neqibzadeh, Mir Abdolhossein and Nowroozi, Reza Ali, 2010, An analysis of the goals of moral and social education from the point of view of Habermas, with an emphasis on communicative action, Journal of Applied Sociology, No. 1, 142-123.

[55] Nikipi, Masoud, 2011, Urban Governance Analysis and Analysis in terms of Citizenship Participation, Case of Yasuj City, Master's thesis, Faculty of Geography, Tehran University, Tehran.

[56] Paya, Ali, 2008, Critical Remarks on the Experience of Iranian Modernity, Quarterly Journal of Hikmat and Philosophy, No. 30.

[57] Ploy, Suebvises. (2018). Social capi tal, citizen participation in public administration, and public sector per formance in Thail and, World Development Volume 109, September 2018, Pages 236-248.

[58] Rakodi, C. (2001).Forget planning, put politics first? Priorities for urban management in developing countries. International Journal of Applied Earth Observation and Geo-information, Vol. 3 ,(3):209-223.

[59] Ran, B. (2012). Evaluating Public Participation in Environmental Policy-Making. Journal of USChina Public Administration, 9 (4), pp. 407-423.

[60] Restemzadeh, helper, Azari suffering, Mohammad and Naderi, Se yyed Hamid, 2010, Methods of assessing citizenship behaviors in urban spaces in a meta-analysis approach, Journal of Environmental Science and Technology, No. 3.

[61] Richard, Elelmana. David, L. Feld manb. (2018) The future of citizen e ngagement in cities, The council o f citizen engage ment in sustainable urban strategies (ConCensus), Futures, Volume 101, August 2018, Pages 80-91.

[62] Safayipour, Zahra, 2016, Investigating the Factors Affecting Public Participation in Urban Development, A Case Study of Ilam City, Quarterly Journal of Urban Development Studies, No. 1, 140-111.

[63] Salahi, Reza, 2009, Proceedings in Urban Planning and Management, Research Institute for Strategic Studies, Tehran.

[64] Takvaei, Masoud, Baba Nasab, Rasool and Mousavi, Chamran, 2009, An Analy sis of Measuring the Effective Factors on Citizen Participation in Urban Management, Case Study: Tabriz Region 4, Urban and Regional Studies and Researches Journal, No. II, 3619th

[65] Thazjaribi, Jafar a nd Safari Shali, Reza, 2010, Interaction in the co ncept of citizens hip and social security, Quarterly Journal of Security and Police

[66] Watson,V.(2002).The Usefulness of Normative Planning Theories in the Context of Sub-Sahahran Africa. Planning Theory, Vol. 1 (1): $27-52$. 
[67] Webler, T. Tuler, S. \& Krueger, R. (2001). What Is a Good Public Participation Process? Five perspectives from the Public. Environmental Management, 27(3), 435-450.

[68] Yang, K., \& Pandey, S. K. (2011). Further Dissecting the Black Box of Citizen Participation: When Does Citizen Involvement Lead to Good Outcomes. Public Administration Review, 71 (6), pp.

[69] Yetano, A., Royo, S., \& Acerete, B. (2010). What is Driving the increasing Presence of Citizen Participation Initiatives? Environment and Planning C: Government and Policy, 28, pp. 783-802. 